\title{
Cultural and cognitive aspects of string figure- making in the Trobriand Islands
}

\section{Éric Vandendriessche}

\section{Q OpenEdition \\ 12 Journals}

\section{Electronic version}

URL: http://journals.openedition.org/jso/7182

DOI: $10.4000 /$ jso. 7182

ISSN: $1760-7256$

\section{Publisher}

Société des océanistes

\section{Printed version}

Date of publication: 15 December 2014

Number of pages: 209-224

ISBN: 978-2-85430-118-2

ISSN: 0300-953x

\section{Electronic reference}

Éric Vandendriessche, «Cultural and cognitive aspects of string figure-making in the Trobriand Islands », Journal de la Société des Océanistes [Online], 138-139 | 2014, Online since 15 December 2017, connection on 30 April 2019. URL : http://journals.openedition.org/jso/7182 ; DOI : 10.4000/jso.7182

(C) Tous droits réservés 


\title{
Cultural and cognitive aspects of string figure- making in the Trobriand Islands
}

by

\author{
Éric VANDENDRIESSCHE*
}

\begin{abstract}
The practice of string figure-making has long been carried out in many societies, and particularly in those of oral tradition. It consists in producing geometrical forms with a loop of string, using mostly the fingers, and sometimes the wrists, the mouth or the feet. This article deals with some of this practice's cultural and cognitive aspects in the Trobriand Islands, Papua New Guinea. Various ethnographical sources suggest that string figures are (or were) subject to ritual prescriptions, and performed for their ritual efficacy in relation to the fertility of gardens. Besides being a popular recreational activity, often accompanied by a recitative, string figure-making in the Trobriands can also be seen as a specific way to talk about sexuality, and as a memory support to remind people of social obligations or of particular stories or events.
\end{abstract}

KEYwords: string figure, Papua New Guinea, Trobriand Islands, Kilivila, procedures, operations, (knowledge) transmission

String figure-making is a procedural activity which has been practiced for a long time in many societies, and especially in those of oral tradition. It has first been documented in the end of the $\mathrm{XIX}^{\text {th }}$ century, in the context of diffusionism, when anthropologists started considering the comparison of string figure corpora as a way to get indications on the contacts established between different societies and on the migratory

\section{RÉSUMÉ}

L'activité communément appelée "jeux de ficelle" est pratiquée de longue date dans diverses sociétés, particulièrement dans celles dites de tradition orale. Elle consiste à appliquer à une boucle de ficelle une succession d'opérations effectuées avec les doigts, mais aussi parfois avec l'aide des dents ou des pieds, pour obtenir une figure finale. Cet article présente certains aspects culturels et cognitifs de cette pratique chez des Trobriandais de Paponasie NouvelleGuinée. Plusieurs sources ethnographiques suggèrent que les jeux de ficelle y sont (ou étaient) sujets à des prescriptions et se voient (voyaient) reconnaître une efficacité rituelle en lien avec la fertilité des jardins notamment. Au-delà du divertissement, ces jeux trobriandais, qui saccompagnent souvent d'un récitatif, permettent de parler de sexualité et sont des supports de mémoire rappelant certaines règles sociales, des histoires populaires ou des événements particuliers.

Mots-cLÉs : jeu de ficelle, Papouasie Nouvelle-Guinée, îles Trobriand, Kilivila, procédures, opérations, transmission de savoirs

routes followed by some populations. The first technical description of string figure-making is due to Franz Boas who collected, in the early 1880 s, the methods of construction of two "Eskimo" string figures (1888: 229-230). Soon after, drawings illustrating the different stages in the making of two string figures known by the Salish Indians (in British Colombia) were published by archaeologist and ethnologist

\footnotetext{
* Université Paris Diderot, Sorbonne Paris Cité, Science-Philosophie-Histoire, umr cnrs 7219, eric.vandendriessche@univ-paris-diderot.fr
} 
Harlan I. Smith (1900). The first significant study on string figure-making was however carried out by Alfred Cort Haddon and William H. R. Rivers in Melanesia. In 1898, they collected the methods of construction of 31 string figures from the Torres Strait Islanders, which led them to elaborate a nomenclature (Rivers \& Haddon, 1902, Haddon, 1912). Their goal was to induce other anthropologists to collect string figures in different societies (Rivers and Haddon, 1902: 147). The various collections of string figures published over the $\mathrm{xx}^{\text {th }}$ century, using Haddon and Rivers' nomenclature or other similar ones, show that this actually happened (Gray, 1903; Cunnington, 1906; Parkinson, 1906; Jayne, 1906; Landtmann, 1914; Jenness, 1924; Hornell, 1927; Paterson, 1949...).

In the Trobriand Islands, Papua New Guinea, the practice of string figure-making was first documented in the 1920 s by Bronislaw Malinowski (1929: 336-338), and then, in the 1980s by ethnolinguist Gunter Senft and his wife Barabara Senft (1986). As I noticed while carrying out fieldwork in 2006 and 2007, string figuremaking (kaninikula) is still practiced nowodays in that part of the world. In these islands, making a string figure requires to make a loop by knotting the ends of an approximately two-meter-long thin string - which is made by tightly plaiting fibres (im) extracted from the roots of a pandanus tree named keibwibwi. The activity then consists in applying a succession of operations to the string, using mostly the fingers, and sometimes the wrists, mouth or feet. This succession of operations, which is generally performed by an individual and sometimes by two individuals working together, is intended to generate a final figure. The making

Picture 1. - Morubikina, displaying the final figure of samula kayaula (a particular river), Oluvilei, Trobriand Islands, Papua New Guinea (picture Vandendriessche, 2007)

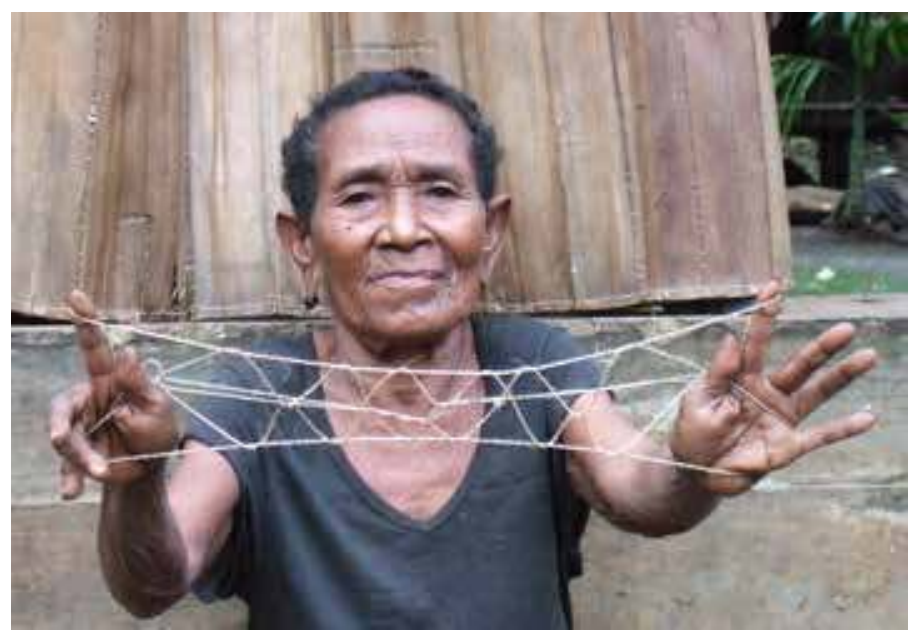

of this figure is often accompanied by a song or a recitative (vinavina).

In this article, I will focus on some cultural and cognitive aspects that I have noted while collecting the methods of construction of these figures from Trobrianders of various generations. After presenting the context and the methodology of my research on string figures in the Trobriand Islands, I shall show that some ethnographical sources suggest that string figure-making is (or was) sometimes subject to ritual prescriptions, and performed for their ritual efficacy, for their positive impact on gardens in particular. Then, we shall see that, besides being an exciting recreational and entertaining activity, the practice of string-figure making in these islands might have been there both a way to talk about sexuality and a reminder of some social prescriptions. Lastly, some ethnographical observations allow us to hypothesize how Trobriander string figure practitioners perceive the processes involved in string figure-making.

Since most of the time I spent with practitioners was used to learn and record how to make these figures, the following outcomes are to be seen as first steps which, I hope, will pave the way towards further anthropological studies on that subject.

\section{Studying string figure-making on the Trobriand Islands}

\section{Location and livelihood}

The Trobriand Islands form an archipelago of coral atolls, with a total land area of about $440 \mathrm{~km}^{2}$, located off the east coast of the mainland of Papua New Guinea. It consists of a main Island called Kiriwina ${ }^{1}$ (approximately $48 \mathrm{~km}$ by $16 \mathrm{~km}$ on its largest part), where most of the population of 20,000 indigenous inhabitants live. It also includes three other smaller islands, Vakuta, Kaile'una and Kitava (as well as a number of small islets which are either uninhabited or with only a few inhabitants). In this region, the climate is tropical with two main seasons: the rain season from December to April and the dry season from May to November. During the dry season, Trobrianders spend most of their time working in their gardens, which are essential for providing food. They cultivate mostly yams, taros, manioc, sweet

1. Malinowski refers to the island of «Boyowa» instead of «Kiriwina». The name «Boyawa» is not often used nowadays. According to Malinowski, "Kiriwina» was at that time the name of a district of the island. 


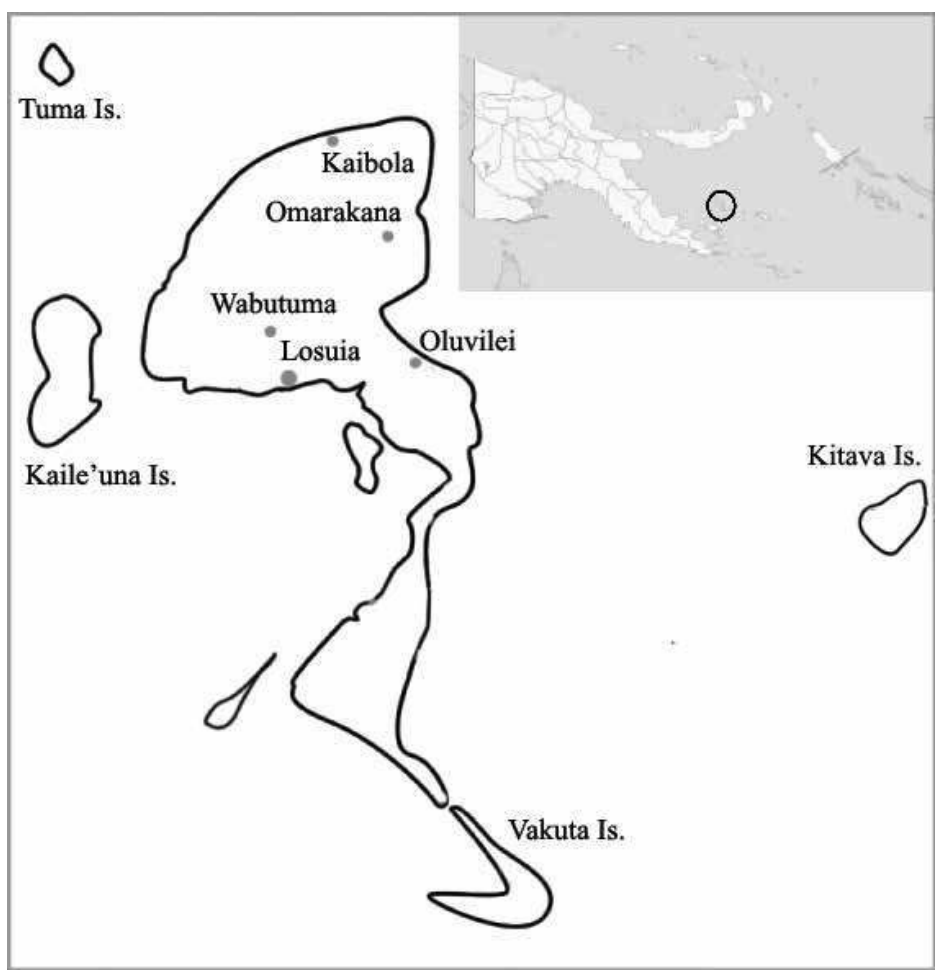

Picture 2. - Trobriand Islands, Milne Bay Province, Papua New Guinea figure-making. However, most of the practitioners are women or children. Thirty years ago, the Senfts made the same observation about the neighboring Kaile'una Trobrianders. Although string figure-making was practiced by both females and males from childhood to old-age, it was generally described by the Kaile'una Islanders as a female activity: statistical outcomes corroborated this, suggesting that the most knowledgeable in string figure-making would have been the Kaile'una middle-aged women (Senft \& Senft, 1986).

Although I met in Oluvilei a few male practitioners, there were mostly women who were able to do all the procedures of the corpus known in the village (including the most complicated ones); they were also the ones able to perform string figure procedures slowly, by clearly dissociating each operation $^{4}$. potatoes, and some green vegetables. The harvest of yams takes place each year between June and August. The tubers are then placed into the "yam houses» (bwema), to be consumed throughout the year. Life in the Trobriand Islands is punctuated by the two tropical seasons and their effects on gardening. The year is thus divided into two different periods: half of the year (May-November) is devoted to planting, fencing, weeding, harvesting, cutting, and burning the gardens to get them ready for the next planting, and the other half (December-April), when no gardening is done, is devoted to other activities such as woodcarving, weaving mats and string figure-making. My fieldwork took place in JuneAugust 2006 and 2007 in the village of Oluvilei ${ }^{2}$ located about $10 \mathrm{~km}$ from Losuia on the eastern coast of Kiriwina, in the district of Luba ${ }^{3}$.

In this village, nowadays, there are men and women of all ages who can perform string

\section{Methodology}

My first investigations on string figure-making were carried out in an ethnomathematical perspective. After comparing different corpora collected by anthropologists, explorers or enthusiasts in different societies, I demonstrated that the process of making a string figure can be analyzed as a series of "simple movements» or «elementary operations» in the sense that the making of any string figure can be described by referring to a certain number of these operations. A string figure can be seen as the result of a procedure consisting of a succession of elementary operations (pictures $3 \mathrm{a}$ to $3 \mathrm{~d}$ illustrate the elementary operations "picking up" and "twisting»). The creation of string figures can thus be regarded as the result of an intellectual process of organizing elementary operations through algorithms based on investigations in complex spatial configurations (Vandendriessche, 2007, 2010).

2. Malinowski refers to this village as «Olivilevi» (Malinowski, 1922: 68). I have chosen to use the writing «Oluvilei» since it has been given to me by some literate villagers. Moreover, it is indeed phonetically closer than the way it is pronounced nowadays.

3. The Trobriand Islands are divided into twelve districts: Kudouya (Northernmost), Tilataula (Central West), Kilivila (Central), Kulupasa (West), Kuboma and Pelosi (Southwest), Kulumata (Southwest coast), Luba (Central south), Kaibwagina (South), Yaiwau (Vakuta Is.), Kitava (Kitava Is.), and Kaile’una (Kaile’una Is.). This division was originally related to local cultural differences such as linguistic variations, and the various churches subsequently used these districts to organize their own activities.

4. It seems to me that there is here something which differentiates a good practitioner from an expert. Let me risk an analogy with music. Most musicians (even good ones) memorize a melody as a whole continuous process. So, without reading the music, it is difficult to stop playing at a point and restart at the same point, or to play a short part of the melody without starting at the beginning of it. For a jazzman, who has memorized a fast tempo bebop theme, it is often difficult to play it as slowly as a ballad in breaking up the melody. As far as I know, there are only a few great musicians who can do so. This suggests that they memorize music as a continuous object as well as a sequence. 

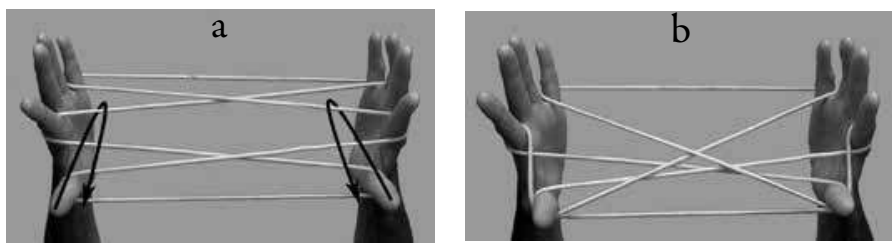

3a and 3b: Operation «picking up» (a string).
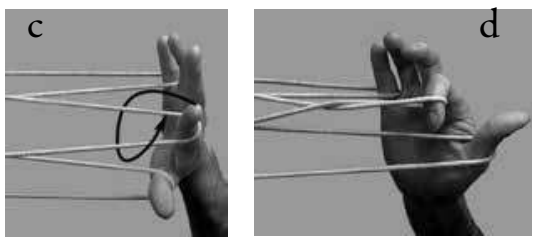

$3 \mathrm{c}$ and 3d: Operation «twisting» (a loop).

Picture 3. - Elementary operations "picking up» and «twisting» (pictures Vandendriessche, 2007)

At this point in my research project, I felt that it was absolutely necessary to collect my own fieldwork data, as I was convinced that the opportunity to meet with practitioners would provide crucial information about the methodology used to create string figures, about the mechanisms of the transmission and the memorization of these procedures, as well as on the cultural contexts of this practice. Unlike the previous researchers on string figure-making in the Trobriand Islands, I have collected the procedures that allow to display these figures rather than only focusing on the final figures. To collect and encode string figure procedures, I have developed a symbolic notation for these algorithms. A corpus of string figures can thus be transcribed as a list of formulae statistically analyzable through computer tools (Vandendriessche, 2010: 393-402).

In Oluvilei, my main informants were a woman in her sixties, Morubikina, who was considered by her co-villagers as the most knowledgeable person in string figure-making, and two women in their forties, Morubikina’s daughter (Bosioula) and Bowelogusa. They taught me how to make most of the string figures I could observe in the Trobriands during my fieldwork. Close relatives of these informants taught me a few other figures. Finally, the rest of the corpus I collected was taught to me by children, boys and girls. I have recorded 68 string figure procedures in Oluvilei, asking my informants to demonstrate all of the procedures they could remember 5 : 58 of these procedures are performed by an individual, 4 by two individuals playing together, and 6 appeared to be «tricks» ${ }^{6}$.

In order to learn the different procedures, I found it necessary to concentrate on working for some time with only one practitioner, being able to repeat the same string figure operations as many times as necessary, step by step. Most of the time, my request for repetition was well accepted by the most experts in string figuremaking, like Morubikina, who transmitted me their knowledge with utter patience.

It was often difficult to make villagers understand my desire to first work with only one person. Many of them knew how to make a few string figures, and some of them would often try to interrupt the sessions to show what they were able to do. This behavior could be directly linked to my visible interest in string figures. However, it could also be indicative of the recognition and prestige associated to the mastering of these figures.

After the collecting process, the formal working sessions became informal meetings. Together with Morubikina, Bosioula, Bowelogusa, and other villagers, we practiced at night, after dinner, in the light of a kerosene lamp on a veranda, which is nowadays the usual spatio-temporal context for practicing string figure-making.

Although Morubikina, Bosioula and Bowelogusa have a high level of competence in string figure-making, they do not claim to have the ability or even the desire to invent new string figures. In addition to being known as the most knowledgeable in string figure-making, they are also considered by their co-villagers as the persons who keep the memory of this traditional practice. These testimonies could be an indicator of how stable the corpus of string figures known in this village might be.

\section{Ritual prescription and ritual efficacy in string figure-making}

\section{On the past and present contexts of the practice}

According to Morubikina, who grew up in the 1950 s in Oluvilei, string figure-making used to be practiced at that time mostly during the yam harvest season (which roughly corresponds

5. All the procedures I refer to are accessible on the String Figure Algorithms website (S. F. A. website): http://www.rehseis.cnrs.fr/www/vandendriessche/StringFigureAlgorithms.html. Every string figure procedure is referenced with a number followed by its name in vernacular language, and the instructions are accessible from the page entitled "Kaninikula Corpus». The references to these procedures will be summarized as ['number' - S. F. A]. The references to the entry "Videos"will be mentioned in the text as [Video 'number'- S. F. A].

6. «Trick» is the term chosen by Haddon \& Rivers for «knots or complicated arrangements of strings which [generally] run out freely when pulled» (1902: 147). In Oluvilei, the procedures performed by two partners are called sowa (saw), takwau (two sharks), tapwawa (child), tagegila (meaning forgotten) and the tricks are tutulobasi, tokwemtuya, daweku and mistakammistamum, whose the meaning of the name were forgotten, and im (pandanus roots) and finally boku (to cough). 
to June and July). However, she was the only person to give me this information whereas my informants (of various generations) usually mentioned the rain season as the "traditional» right time (in the present and the past) for practicing string figure-making. Morubikina's testimony corroborates information collected by anthropologist Diamond Jenness on Goodenough Island, in the D'Entrecasteaux archipelago, in the 1910s. On these islands that belong to the Kula ring first studied by Malinowski (1920, 1922), and are relatively close to Kiriwina, string figure-making seems to have been prohibited except during a particular harvesting season. Following an information that was given to him by the Rev. A. Ballantyne, who was a missionary on Goodenough Island for many years, Jenness underlines that:

«The proper time for playing the game (Cat's Cradles) $)^{7}$ is at the mwamo (a root similar to the yam) harvest. At all other times the old men prohibited them lest they should bring disaster on the gardens. As the mwamo harvest is immediately followed by the planting of yams, which are the principal food of the natives, it would seem that the playing of Cat's Cradles is beneficial for the gardens.» (1920: 300)

On Goodenough Island, the practice of string figure might thus have been embedded into a system of prohibition/prescription - in its link to positive or negative impacts on gardens - which entailed that string-figure making was prohibited during the rain season, and encouraged only a few weeks during the dry season. Nevertheless, in the same years (1910s), Malinowski made a different observation about the Trobriand Islands, which corroborates my informants' testimonies (with the exception of Morubikina).

«String figures or Cat's-cradles (ninikula) are played by children and adults in the day time during the rainy months from November till January, that is, in the season when the evenings are passed in reciting folktales. On a wet day, a group of people will sit under the overhanging roof of a yam house or on a covered platform and one will display his skill to an admiring audience.» (Malinowski, 1929: 336)

Even though Malinowski travelled throughout the region (the Trobriand archipelago and nearby islands) to carry out his research about the Kula, he was based at Omarakana in the district of Kilivila (Central Kiriwina). This village has a central place in his book The Sexual Life of Savages in Northwestern Melanesia (1929) in which he devotes a short section to string figures. Hence, one may suggest that he made his observations about string figures in this village of the center of Kiriwina, and that string figure-making usually took place, here, at the beginning of the rain season in the 1910s.

Nowadays, in the Trobriands, string figuremaking mostly takes place during the rain season. But the above testimonies suggest that, at least in the past, the period for making string figures might have varied from one place to another in the Trobriands and nearby Islands. This apparent contrast between neighboring cultural groups should invite us to take a very close look, in the future, at the plausible causes of these variations. Further ethnographical research need to be carried out in that perspective. This should be done in particular in connection to the transformations of social forms that seem to occur in the Kula ring, from one society to another, as Frederick Damon demonstrated through the comparison of Trobriand and Muyuw societies (Damon, 1990).

The above extract by Jenness also underlines that string figures were in some particular contexts performed for their ritual efficacy, having a positive impact on gardens, in the growing of yams in particular. We will see in the following that other hints seem to indicate such a connection. One of these is the etymological interpretation of the term used by my informants to refer to string figure-making.

\section{On the etymology of the vernacular name of string figure-making}

In the village of Oluvilei, all my informants refer to string figure-making by using the term kaninikula. More generally, the same term seems to be used on Kiriwina Island, as well as on Vakuta Island ${ }^{8}$. Linus Digim'Rina, an anthropologist at the University of Papua New Guinea, suggests that kanini may literally mean "to peel/husk/skin with ones teeth", while the term kula would be derived from the verb kuri, and mean "how to gain» (Digim'Rina, pers. com. 2010). If the translation of kanini by the verb «to peel»is also given by Senft (1986: 539) without mentioning the use of the teeth however - the etymology of kula remains an open issue. The anthropologist Johnny Persson suggests for his part that kula and kuna (rain) might have the same etymological root, referring to the «same

7. The «cat's cradles» is a procedure performed by two individuals playing together. It is well known - at least since the end of the XIX ${ }^{\text {th }}$ century - in Europe, America and Asia. The expression "cat's cradles» was often used at the beginning of the $\mathrm{xx}^{\mathrm{th}}$ century to refer to the practice of string figure-making in general (Rivers \& Haddon, 1902: 146).

8. On Kaile'una, string figures are called ninikula (Senft \& Senft, 1986). According to Gunter Senft, this difference is due to dialectal variations which occur from one linguistic area to another in the archipelago (pers. com. 2010). About the linguistic areas on the Trobriand Islands, see (Senft, 1986: 6-11). 
imaginary reality based on notions of wealth and fertility» (Persson, 1999: 199).

According to this information, the literal meaning of kaninikula could be "how to gain/ to make growing/(a string figure, implicitly) in peeling/operating with ones' teeth». As regards Digim'Rina's interpretation of the root kanini, it is worth noting that it concurs with a characteristic of the practice of kaninikula in the Trobriand Islands, where the teeth are often involved in the making of these figures. The previous interpretation of the literal meaning of the term kaninikula thus suggests a possible link between the gestural and verbal aspects of the practice of string figure-making, and the notions of "growing» (how to gain) and "fertility» as well as the action of "peeling» or «skinning" tubers.

\section{Plaiting the string for performing kaninikula}

In Oluvilei, the only person entitled to plait or make strings out of the fibre of pandanus roots is an old man, Buyailakilivila, who is recognized as a specialist of this plaiting technique [Video 12 - S.F.A.]. The strings thus plaited, called $u l i k u d u$, are used for string figure-making, and also for other purposes such as making traditional skirts, necklaces, or for setting up a trap. Such strings are also used for tying up the leaves put on the deceased. Depending on their uses the strings are of different diameters or lengths. Buyailakilivila himself emphasizes that he has learnt the technique of fibre-braiding by watching the elders. The only person to whom he has transmitted this skill is his son, a hunter who needs strong strings for his traps.

The fact that only one person in the village is in charge of string-making suggests that this activity itself may have a ritual function (that may be transmitted from father to son).

Another hint seems to support this assumption: I was asking Buyailakilivila whether he knew traditional stories or myths mentioning the practice of string figures. Although he did not know such stories, he went on to say that he sometimes sings some particular songs (wosi milamala) while plaiting the strings, as it was (according to him) often the case in the past. These songs are generally associated with dances named ilowosi that take place after the yams have been harvested and stored into the houses made for that purpose (bwema): performed in circles, these dances are said to open the milamala period (from July to September) [Video 8 - S.F.A.]. At the beginning of this period, the spirits of the dead (baloma), that normally dwell on Tuma Island, come and visit their former villages (Malinowski, 1916). The wosi milamala are sung to celebrate the baloma's visit, while providing them with food (Senft, 1996). According to
Senft, these songs are also aimed to remind the Trobrianders of the social norms that must be respected even during this extraordinary period, which is characterized by "conviviality, flirtation, and amorous adventures" that may lead to «jealousy and rivalry»; if escalating, the latter may "threaten the community» (Senft, 1996: 386). According to him, the wosi milamala is a form of ritual communication that serves «the function to prevent such a development».

It is also noticeable that the wosi milamala are usually sung

«after the death of a Trobriander and during the first mourning ceremonies. [...] The songs - especially those songs that describe carefree 'life' of the spirits of the dead in their Tuma 'paradise' - may ease the balo$m a$ 's grief of parting; moreover the songs should also console the bereaved, reminding them of the fact that dying is [...] just a transition from one form of existence to another.» (Senft, 1996: 387; see also 2011)

When I asked Buyailakilivila whether he could sing a wosi milamala while plaiting ulikudu, he hesitated for a moment, and finally refused to do it, asserting that «when the spirits tell him to sing, he can sing, otherwise he cannot». Further research is needed to clarify the potential ritual link between the activity of string-making and the interpretation of wosi milamala, but one may suggest that string-making has a connection with some forms of propitiation regarding the spirits of the dead.

As regards more specifically the use of strings to make (geometrical) figures, one may remind that string figure-making was said to be «beneficial for gardens», when performed at the right time (the harvest of mwaimo, a root similar to the yam) on the Goodenough Islands (Jenness, 1920: 300). In Papua New Guinea, among the Kiwai in particular, performing string figures might also have been considered as a way to propitiate the growing of the yams, as the anthropologist G. Landtman reported it in the 1910s. In this society, a string that had been used for making string figures might have thus been regarded as bearing in itself some efficiency for positively impacting the growing of the yams.

"On the whole cat's cradles are regarded by the Kiwai people purely as play, but in certain cases a more particular interest attaches to them. The game is most commonly played when stalks of the newly planted yams begin to shoot up from the earth. Sticks are put in the ground to support the winding tendrils, and the first few stems are tied to them by means of pieces of strings which have been used for making cat's cradle. It is sufficient, however, to hang pieces of these strings on top of the first few sticks without actually tying the stalks with them, and some people merely throw a few pieces of cat's cradle strings here and there on the ground in their gardens. In each case the purpose is to 'help' the stalks of the yams to grow 
well and wind in the right way.» (Landtman, 1914: 221)

On the Trobriands, some examples seem to indicate that such a connection between string figure-making and gardening activity has also occurred there.

\section{String figure-making, magical stones and fertility of gardens}

Tolobuwa, the village chief of Oluvilei, particularly insisted on the string figure procedure dakuna (stone) [46 - S.F.A.] that he considers to be referring to "magic stones». This kaninikula consists of a series of three procedures which differ from one another through the alteration of one and only one elementary operation. The three figures obtained through these three consecutive procedures are shown in the following pictures $4 \mathrm{a}$ to $4 \mathrm{c}$.

This series of figures is punctuated by a recitative (vinavina). While the first figure is shown to the audience the practitioner says: duku yoyowa (they fly away). For the second figure he says: duku yoyowa - luku tota (they fly away - they remain standing). And finally, for the third one: duku tota (they remain standing).

In the Trobriand Islands, many stones are known to be used for various forms of magic. Some of the most widely known are those put into the big yam houses (liku) so that the tubers remain fresh and beautiful for the time they are stored in the liku (Senft, 1997).

However, the stones that the string figure dakuna refers to do not seem to have the same purpose: according to Tolobuwa, each village chief owns magic stones that he receives from his maternal uncle, and that he himself buries near his yam house (liku) (Vandendriessche, 2012). Each of these stones is said to contain a giant to whom the chief must ask frequently for some help with the gardening. If the chief does not comply with this prescription, the stones move away and never come back. Tolobuwa underlined that the role of the string figure dakuna is thus to remind the chiefs that they have to use their magic stones if they don't want to lose them. The string figure procedure dakuna thus appears as a memory support of a ritual prescription linked to the gardens' fertility.

In their 1986 paper, Gunter and Barbara Senft confirmed that certain string figures, and the words which accompany them, are (or were) used (on Kaile'una) for a magical purpose, and for their positive impact on gardens' fertility. It is (or was) the case for the string figure simsimwaya (sweet potatoes). The following text is declaimed by the gardener after having made the figure.

\section{Simsimwaya - The sweet potatoes \\ Kwemvara kwemvara - Potatoes, potatoes \\ Kwemvara - Potatoes \\ Kwege’i kwege’i-Come back, come back \\ Iselaga e dabala - He puts it over his head \\ Bulumaduku tabulumaduku - In February, in February \\ Kwemvara kwemvara - Potatoes, potatoes \\ Kwemvara - Potatoes \\ Iselaga e dabala - He puts it over his head \\ Gilivilai tagiluvilai - In January, in January \\ Kwemvara - Potatoes?}

According to the Senfts, this text can be analyzed as a magic formula which aims to make a better crop (Senft \& Senft 1986: 166). The Trobrianders magic formulae are characterized by the use of «archaic Kilivila words, syntactic constructions, shades of meaning, but also socalled "magic words" and loan words from other Austronesian language», all characteristic to the "Language of Magic" (biga mwega) (Senft, 1986: 126) (Malinowski, 1935). In the example of simsimwaya above, two magical words can be identified: the use of kwemvara for "potatoes" and tabulumadukultagiluvilai for the month names (G. Senft, pers. com. 2013).

To my knowledge, Malinowski does not mention any link between the practice of string figuremaking and the magics of gardening. The only connection between string figures and gardening that he refers to is about a string figure (not named by the author), showing "two men quarrelling while cutting [gardens]». Malinowski explains that, "whatever the cause, quarrelling frequently occurs $[. .$.$] when two people want to cut the same$ plot, [and that] there were long litigations, arising at disputes at cutting.» (1935: 104).

Pictures 4. - The procedure dakuna (stone) (pictures Vandendriessche, 2007)

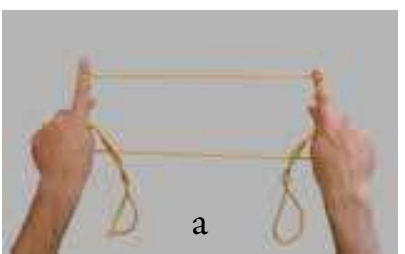

a: First figure.

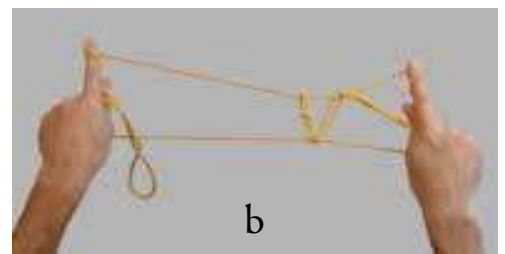

b: Second figure.

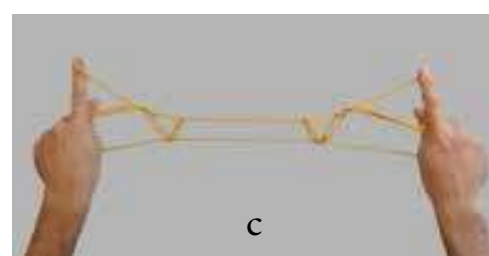

c: Third figure.

9. Text extracted from (Senft \& Senft, 1986: 166), initially translated into German; my translation into English. 


\section{Expressing knowledge through string figures}

Each kaninikula has a specific name in Kilivila. Until now, I have collected 68 of these names. They can be divided into four subsets: 7 names refer to the environment (sea, sun, particular island or river,...), 11 names refer to artefacts made by humans (trap, basket, grass skirt, house...), 18 are names of animals, 8 are names of plants, 15 refer to people or human actions, and finally 9 of the kaninikula known in Oluvilei have names whose meanings are forgotten.

\section{String figure-making and sexuality}

Gunter and Barbara Senft mention that the use of the name of an animal, a plant, a fruit, or an object frequently occur in a metaphorical way in the Trobrianders' everyday life to refer to genital organs, coitus and sexual intercourse. They thus argue that some terms either used to name some string figures or used within some accompanying oral texts (vinavina) actually refer (through metaphors) to sexuality (1986: 103). For instance, the string figure called pwadodoga (name of a man) was accompanied by an oral text which is a strongly metaphoric fictive dialog between a man and a young woman during defloration (1986: 186).

Malinowski had already given examples of some string figures which

«show pornographic details. In "kala kasesa Ba'u" (the clitoris of Ba'u) the performer, after preliminary manipulations, produces a design [...] in which two large loops are formed in the main plane of the figure, while at the bottom of each, a smaller loop sticks out at right angles to the main plane. The large loops each represent a vulva and the smaller ones a clitoris. [...] The figure complete, the artist skillfully wriggles his fingers, producing a movement first in one and then in the other of the clitoris loops.» (Malinowski, 1929: 336) the vinavina. Tokwelasi is the name of a man known as an adulterer, as already mentioned by Malinowski:

"Tokwelasi, the adulterer (c, in fig. 3), is a complicated set and requires both hands, the two big toes and the heels for its composition. The accompanying commentary is just spoken in ordinary prose. The first figure (C, I) is formed, in its significant section, of two isosceles triangles, one above the other and touching by apex. These triangles represent the adulterer and the wife engaged in the act of copulation. To indicate this, strings are manipulated so that the point of contact moves up and down, while each triangle in turn increases and decreases in size. At the same time the artist declares in unambiguous language; "This is the adulterer; this is the wife, they copulate." (Malinowski, 1929: 336-338)

My informant, Tokwakuwa, a 60 year-old man, did not mention the signification of the two triangles. However, he confirmed that the manipulation of the figure, moving the hands up and down represents the coitus between the adulterer and the wife [Video 4 - S.F.A.]. I was also able to notice that the accompanying text was recited by Tokwakuwa in "ordinary prose». Moreover, he was sometimes searching his words, and the vinavina may vary from one performance to another. One of these had the following text, which explicitly refers to an extramarital relationship of a married woman and a man, and also to the punishment: as noted by Malinowski, a husband had the right to kill his adulterous
In this case, it is the figure itself which symbolizes the genital organs. I personally did not find this kaninikula. However, I have learnt how to make the string figure Tokwelasi [55-S.F.A.] which is one of the four string figures that Malinowski mentions in his 1929 book. In this procedure, the connection to sexuality is explicit, both through the manipulation of the final figure (referring to sexual intercourse) and within
Picture 6. - Tokwelasi (name of a man known as an adulterer) (drawing extracted from Malinowski, 1929: 338)

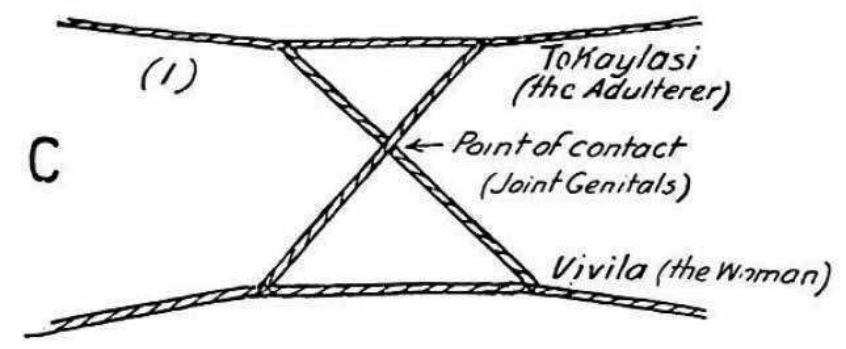


wife, even though the usual punishment was general denigration (1929: 121).

Tokwelasi kala biga - Tokwelasi, his language

Tokwelasi esisu ola bwala - Tokwelasi is in his house

Lakwava sola ehelasi - His wife, with her, they commit adultery

Bwala sola bwala ekatudeva - In the house with her in the house, he has fun

Ekatudeva bogwa elagisi sola kala biga - He has fun already, they hear her friend, his speech

Esakaula ila-He runs he goes

Esakaula ila kala biga bogwa-He runs, he goes, his speech already

Tolimwala kala biga - The true husband, his speech Kutota kuvigivau - You stand up, you do it again

Igau kala biga leolada - Then, his speech on the road Kalituwa kaligeva kaliga - The prize, forget it, death!

(G. Senft's translation - pers. com. 2012)

The explicit reference to the coitus, made at the same time in this vinavina and through the manipulation of the string figure, is one of the reasons why Tokwakuwa refused to perform this kaninikula on a Sunday - as I was asking him to teach me the words of the vinavina he had recited a few days before while making this string figure. On another occasion, also on a Sunday, as Tokwakuwa was performing kaninikula in front of a large audience in the village [Video 5 - S.F.A.], I asked him to make the one called Tokwelasi, and he refused once again, reminding me that he could not perform this procedure on the Lord's day. $\mathrm{He}$ finally taught me the words some days later, in the intimacy of the evening gatherings, on his veranda (Vandendriessche, 2012). The Senfts also refer to the string figure Tokwelasi (1986: 212). However, the vinavina they have collected in Kaile'una is slightly different from the (above) Olivilei version of this oral text:

\section{Tokwelasi-Tokwelasi}

Tokwelasi bila va bagula - Tokwelasi goes to the garden Bibani natatala vivila - He meets a young woman there Ebikelasisi - They commit adultery ${ }^{10}$

As noted by the Senfts, in this case, the text refers to two major taboos in the Trobriand Islands: adultery - as in the previous version - and sexual intercourse in the gardens. It is said that the transgression of this taboo implies that the man would «get elephantiasis (of the testicles).
The woman likewise would get elephantiasis (of the labia)» (Malinowski, 1935a: 119). It is also believed that «intercourse in the gardens is punished by a special visitation: the bush pigs are attracted by the smell of the seminal fluid, they break through the fences and destroy the gardens» (Malinowski, 1929: 415).

The reference to sexuality either (or both) through the (gestural) procedure or/and through the (accompanying) oral text can be either explicit (as for Tokwelasi) or merely suggested as in the vinavina which goes with the making of the figure Mbanekua that I have collected [58 and Video 15 - S.F.A.]. This oral text begins by the following verses which are quite suggestive:

Tobanekwe - Tobanekwe (name of a man)

Kukeulai mpanana - You carry your flexible thing

Kwataila osisuna uиu uuu! - This thing goes behind the house, uuu!

Kwe bimapusi iyowaisi - They give it to each other, they fight

(G. Senft's translation - pers. com. 2012)

According to Gunter Senft, the "flexible thing" refers to Tobanekwe's penis, and the fourth verse should be read as a reference to sexual intercourse.

Like Malinowski and the Senfts, I was thus able to notice relationship between string figure-making and sexuality. However, it was sometimes not easy to make my informants comment on this aspect, as illustrated by the following testimony.

There is a string figure (procedure) which is known as tubum in Oluvilei [27 - S.F.A.]. When I asked Morubikina about the meaning of this word, she said that she did not know it, and she mentioned that, to her knowledge, this string figure procedure was not accompanied by any oral text.

Later, as I was staying in the village of Wabutuma in South Central Kiriwina, some local practitioners told me that this procedure (tubum) was called kwetabum in Wabutuma, and that was there accompanied by a vinavina. When I returned to Oluvilei, I asked about the meaning of the words used in this vinavina, and about the meaning of kwetabum. I was told that this term refers to «a boy sleeping with his grandmother (bubu)», which is also clearly evoked in the
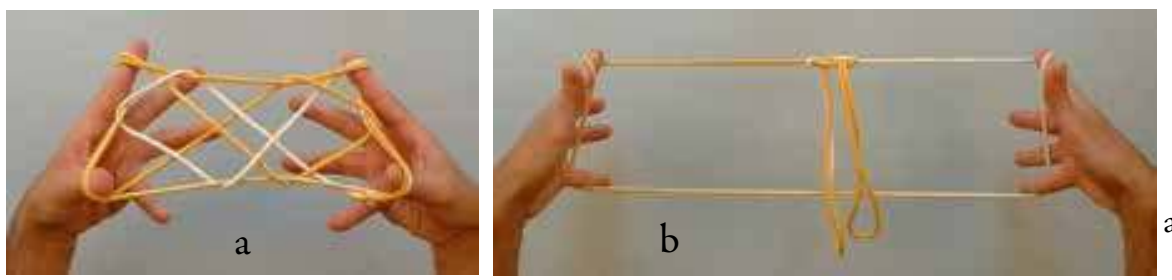

Pictures $7 .-$ Intermediate and final figures of tubum (Vandendriessche, 2007)

a: Intermediate figure. b: Final figure.

10. Text extracted from (Senft \& Senft, 1986: 212), initially translated into German; my translation into English. 
accompanying oral text. This vinavina thus refers to an incestuous relationship. Although not comparable to the sister-brother incest taboo which is the supreme one (Malinowski, 1929: 437; Weiner, 1988: 76) - as noted by Malinowski, «the maternal grandmother and her grandson are also sexually forbidden to each other, but there is no horror about this relationship, such incest appearing as a merely ridiculous possibility» (1929: 441).

I questioned Tolobuwa (the chief of the village of Oluvilei) about the meaning of tubum in Oluvilei and the name found in Wabutuma. Since he did not know, he asked Morubikina to come. She joined us and revealed that tubum and kwetabum have exactly the same meaning as they both refer to the same story. Morubikina did not tell me why she had hidden this to me, but it might have been that the story tubum tells of a behavior that contemporary Trobrianders do not like to discuss in public, because of the influence of the church (United Church).

From my observations in Oluvilei and other places in the Trobriands, it is obvious that Trobrianders enjoy performing string figures nowadays. Kaninikula and their attached vinavina clearly provide a form of entertainment for the practitioners, but also for the onlookers. Most of the time, whenever I could observe Trobrianders performing kaninikula as a play in front of an audience, the goal of these performances was clearly to make the audience laugh. I could notice that the reference to sexual intercourse, as in Tokwelasi and Mbanekwe, causes laughter systematically. In some other cases, laughter is provoked by scatological references. For instance, the string figure gwadi (child) represents a baby carried by the practitioner, that he/she wants to entrust to somebody else because the child is dirtied with his own excrement. Tokwakuwa showed me once how the performance of this kaninikula can make Trobrianders of all ages laugh and revel [Video 5 - S.F.A.].

It is likely that my informants chose not to reveal the metaphorical meaning of some kaninikula implying sexual or scatological references. It is also probable that I did not collect the whole corpus of vinavina: it is often said that there were many more in the past and Trobrianders admit quite readily that a lot of these texts were connected to sexuality. The vinavina may have been forgotten under the prevailing Christian ideology, or they may be hidden and transmitted confidentially.

\section{String figure-making as a memory support}

The previously discussed example of dakuna, tubum and Tokwelasi suggest that the making of some kaninikula is (or was) intended to remind the Trobrianders about certain knowledge linked to social rules or to particular stories or events.

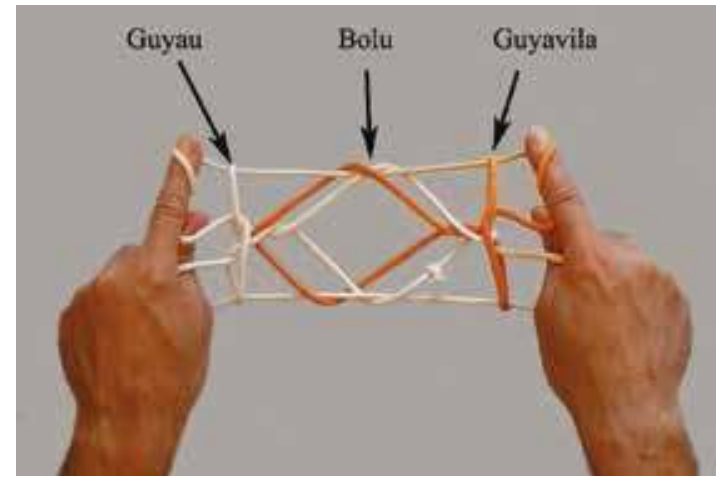

PiCture 8. - The final figure guyau-bolu-guyavila (chief - cup - chief's wife) (picture Vandendriessche, 2007)

Another interesting example is given by the string figure procedure guyau-bolu-guyavila [24 - S.F.A.]: guyau means "chief", guyavila is the chief's wife, and bolu is a bowl or a cup. The chief of Oluvilei (Tolobuwa) informed me that every chief on the Trobriands owns a bowl, that he only can use, while his wife is the only one allowed to pour water or soup into it. According to Tolobuwa, it is this rule which is underlined and thus called to memory - in the string figure called guyau - bolu - guyavila.

Kala tugebi navalulu [8 - S.F.A.] is another example of string figure-making which also refers to an important prescription. Kala tugebi means "carry on the head", and navalulu means "woman in childbirth». According to my informant Bowelogusa, this name refers explicitly to the headdress (or linen) worn by women leaving the house for the first time after giving birth. Its function is to prevent evil spirits from entering their bodies and spoiling their milk. This is also underlined by a particular operational gesture within the string figure-making process: the first step of the procedure kalatu gebi navalulu consists in making a small loop which is gripped between the teeth; the rest of the string is then placed over the head as the headdress should be (picture 9).

In Oluvilei, I collected 18 string figures which are accompanied by a recitative (vinavina). These oral «texts» are of various lengths and recited or sung either throughout the procedure - see above the example of Tokwelasi and dakuna, and [Video 1 - S.F.A.] - or after the display of the string figure, as for Mina Kaibola (Man from Kaibola, picture 10) [Video 3 - S.F.A.].

In both cases, the vinavina has to be recited repeatedly no matter how many times it is repeated: even in a teaching situation, when the practitioner has to repeat the figure several times, it is rare that the instructor does not say the accompanying words. Furthermore, I noticed that the vinavina is inseparable from the operational procedure leading to the 

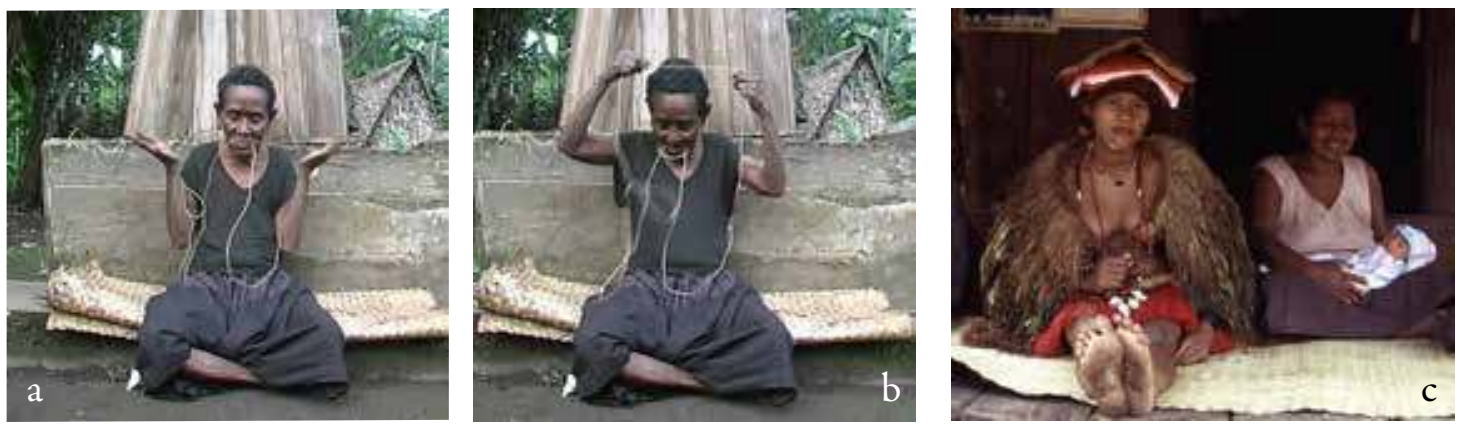

$9 \mathrm{a}$ and $9 \mathrm{~b}$ : Practitioner placing the string over her head.

9c: Headdress worn by a young woman leaving the house for the first time after giving birth.

Pictures 9. - The procedure kalatu gebi navalulu, Oluvilei, Trobriand Islands, Papua New Guinea (pictures Vandendriessche, 2007)

figure when the vinavina is to be interpreted throughout the procedure: I have often observed that my informants were not able to make the figure without «singing" the vinavina (and vice versa). From this perspective, one may suggest that kaninikula and their associated vinavina can constitute genuine memory support for one another: the procedures carried out on the string have helped the performers to memorize the «texts» and reciprocally.

\section{String figure-making and cognition}

\section{Cognitive abilities in string figure-making}

A few experiences I had in Oluvilei provided me with some indications on the way some string figure makers perceive string figure processes. One day, as I was learning a procedure from Morubikina, I asked Bowelogusa, who was cooking a few meters away, whether she knew this kaninikula (which seemed difficult to me). She claimed that she did not, but the following night, she easily displayed the figure during an informal working session. She mentioned that she had learnt to make this string figure simply by watching us from a distance. If this

Pictures 10. - The string figure Mina Kaibola used to mime the movements of a paddler, while singing the vinavina, Oluvilei, Trobriand Islands, Papua New Guinea (pictures Vandendriessche, 2007) assertion was true (as it seemed to be) one may think that the ability of Bowelogusa to capture and memorize a procedure from a distance, is due to many years of practical experience that has given her a high perception of the operations involved in the procedures and their usual organization in «sub-procedures» ${ }^{11}$.

I also notice, in a similar learning situation, that several Trobrianders can instantly grab and reproduce unfamiliar series of operations in string figure-making. As I was in the village of Wabutuma (in the center of Kiriwina Island), some people asked me whether I had found, elsewhere on Kiriwina, some kaninikula which were unknown to them. I decided to demonstrate a procedure that was apparently unknown in Wabutuma, and that I had learnt as kwau (the shark) in the village of Kaibola, on the south coast of Kiriwina. Moreover, as far as I could see, this kaninikula was not comparable to any string figure taught to me in Wabutuma. As this procedure involves two partners, I performed it with the person who had guided me throughout the Trobriand Islands, and who had also learnt the

11. I have defined a «sub-procedure» as any succession of elementary operations either shared, that is, used in the same way in several string figure procedures, or iterated in the same one (iterative sub-procedures). I have demonstrated that the elementary operations involved for the making of string figures are generally the same from one cultural area to another, unlike the sub-procedures: the use of certain characteristic sub-procedures makes differences very clear from one corpus to another (Vandendriessche, 2010: 335-537). 
procedure in Kaibola. The people in Wabutuma confirmed that it was a new procedure for them. But as soon as we ended our demonstration, some observers repeated successfully the same procedure (which seemed quite complex to me). This may indicate that some practitioners are able to internalize very quickly an atypical series of operations.

\section{Procedural aspects of string figure-making}

According to John Kasaipwalova (a Trobriander intellectual and a poet in his fifties), who has a good knowledge of the different dialects spoken in the Trobriand archipelago ${ }^{12}$, the term kaninikula refers to the whole process of making the string figure. This could be related to the ways Trobrianders seem to perceive the process of making a string figure.

In the 1980s, the Senfts wanted to assess the extent to which the string figures were known in the village of Tauwema and its neighborhood. Then, something noticeable happened which seems to confirm the procedural perception of string figuremaking by Trobriander practitioners. Some people were asked to recognize and name the drawings of the string figures that the researchers had previously drawn: to find the name of a given figure, and without using any string, some informants spontaneously performed the movements involved in the making of the figure they where thinking of (Senft \& Senft, 1986). This observation suggests that a string figure is perceived as part of a whole process, and can hardly be dissociated from it.

Furthermore, I was able to observe that, as a general rule, a string figure is usually shown for a few seconds only, before being undone by the practitioner who thus obtains the original loop from which he started the procedure [Video 6 - S.F.A.]. This seems to indicate that a string figure is seen simply as a stage (among others) of the procedure. Moreover, the undoing of the figure appears to be included in the whole process of performing a kaninikula. Invariably returning to the starting point of the procedure, kaninikula procedures seem to have something to do with cycles.

\section{Vernacular terms referring to gestures in string figure-making}

In the language of the Trobrianders (Kilivila), some particular expressions are used to refer to operations involved in the practice of kaninikula (Vandendriessche, 2010: 383-387, 388-390). The existence of these expressions suggests a local perception of the notion of elementary operations revealed by the ethnomathematical analysis.

I was able to note 11 vernacular expressions denoting an action on the string (over a total of 15 elementary operations). For instance, the terms kutasuki and kwatupini respectively refer to the elementary operations of "picking up" (a string) and "twisting" (a loop) (picture 3). Tasuki is the verb «to pick up»; $k u$-tasuki thus means "you pick up». $K u$ + verb is the general grammatical form of the expression used by the practitioners in the context of string figure-making: this seems to be linked to the use of this terminology in situations of transmission from one individual to another.

The expression kwatupini also follows this general rule: the verb is actually katupini (to twist), the expression ku-katupini (you twist), saying shortly becomes kwatupini (G. Senft, pers. com. 2013).

The term lupulapu is the only expression referring to what I call an elementary operation which has not been given to me in the form $k u+$ verb. It refers to the picking up of a string through a small loop, as described in picture 11 [53 - S.F.A.]. This term lupulapu seems to be used exclusively in the context of string figuremaking (G. Senft, pers. com. 2010). Furthermore, an apparent feature of this operation is its low occurrence in the corpus.

Although numerous sub-procedures - i.e. any succession of elementary operations used in the same way several times within the corpus - come into play in the making of kaninikula, it seems that only three of them - all consisting in a small

PICtURes 11. - Operation lupulapu (pictures Vandendriessche, 2007)
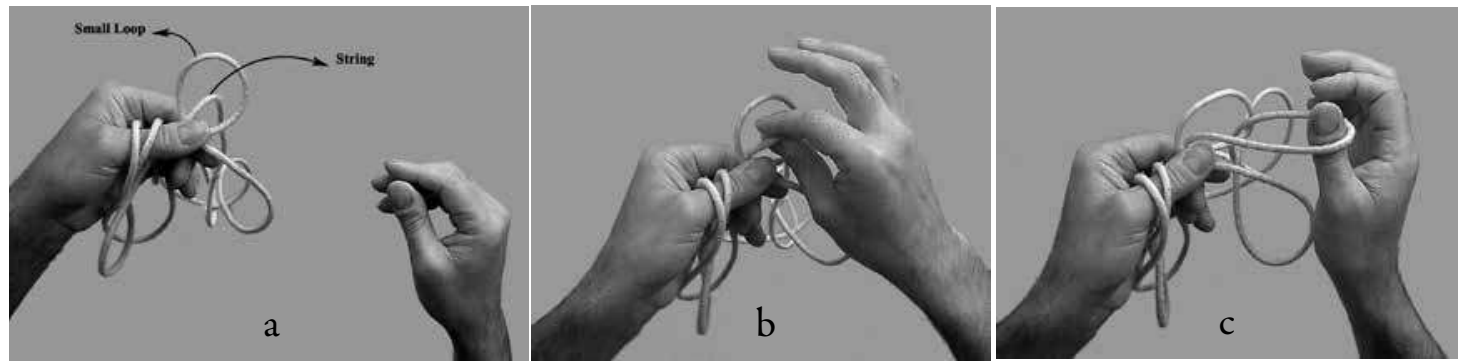

12. There are at least four mutually understandable local dialects mentioned by the Trobrianders themselves (Senft, 1986: 6). 

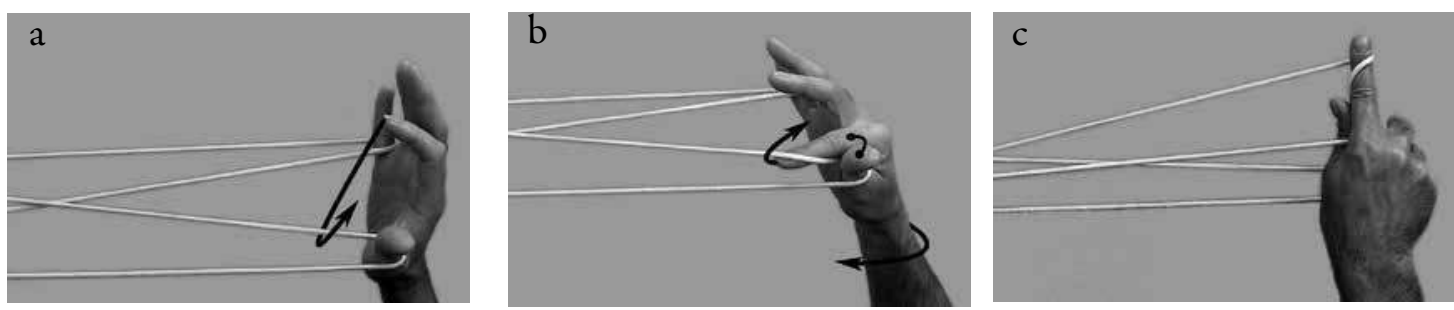

Pictures 12. - Sub-procedure kwatuponiniya (pictures Vandendriessche, 2007)
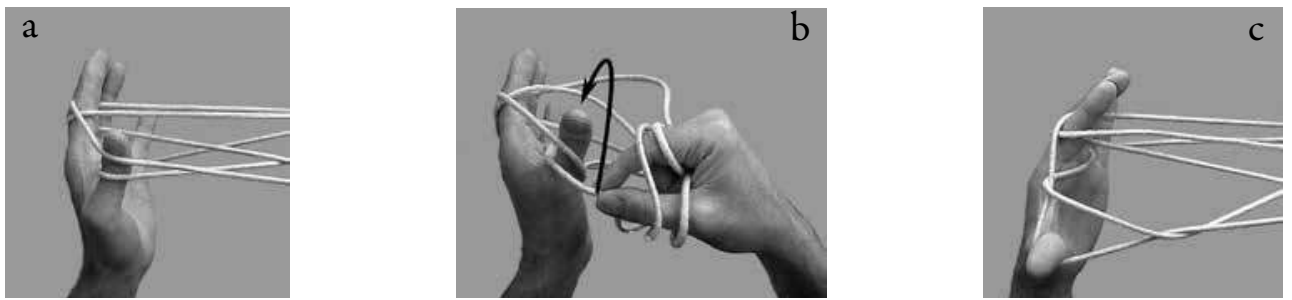

Picture 13. - Sub-procedure kwalili (pictures Vandendriessche, 2007)
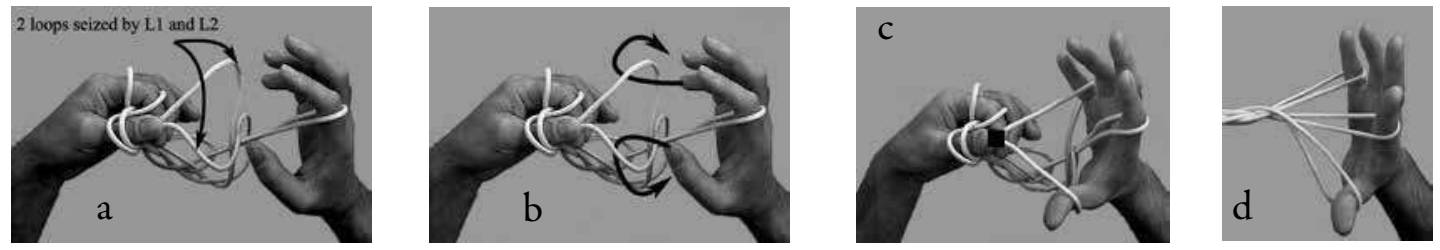

Picture 14. - Sub-procedure sosewa (pictures Vandendriessche, 2007)

number of elementary operations and having a high occurrence in the corpus - are explicitly named in Kilivila. Furthermore, these three «technical» terms do not seem to be used in another context. One of these terms is kwatuponiniya, which refers to the short sub-procedure shown in picture 12. The two other (specific) terms are kwalili and sosewa, that both refer to short sub-procedures used very frequently in Trobrianders' string figure-making. A string passing around a finger forms a loop. When two loops lie on the thumb, kwalili consists in "grasping" the lower one (using either the thumb and index of the opposite hand, or more often, the teeth) and passing it over the thumb ${ }^{13}$ (picture 13). When two loops are seized between the thumb and the index of one hand, sosewa consists in inserting simultaneously thumb and little finger of the other hand into these loops, which are finally transferred to these fingers (picture 14). All of these technical expressions are used in situations of transmission from one person to another, although not consistently. The kaninikula procedures are indeed taught or shown most often without any technical comments. The existence of these terms however is an indicator of the perception by the actors of orderly sequences of operations.

\section{Progressive learning}

In Oluvilei, most of the children are able to make a few kaninikula and the most skilled among them know about ten kaninikula, which are usually the same ones. The transmission of the latter procedures occurs mostly between peers. This led me to consider a subset of the Oluvilei corpus formed by 13 string figure procedures that I call "Children corpus» - generally known by pre-adolescent children ${ }^{14}$.

The statistical comparison of the elementary operations and the sub-procedures involved in the Oluvilei-adult corpus and the Children corpus suggests a progressive learning of string figure-making in childhood. First, the mean number of elementary operations per string figure is significantly different from one corpus to another (full Oluvilei corpus: 32.7 / Children corpus: 15.7): it appears that the procedures known by children are roughly twice as short as the ones of the full Oluvilei corpus. Secondly, the occurrence of certain operations may vary significantly from one corpus to another: for instance, the sub-procedure sosewa (see above) occurs with a mean number of 0.33 per procedure in the Oluvilei Corpus, whereas it is not involved

13. This sub-procedure is involved in many corpora of string figures collected on the five continents. It is often termed "Navaho" in the ethnographical literature, terminology used for the first time by Kathleen Haddon (1911), the daughter of A. C. Haddon.

14. This subset is constituted by the procedures numbered 1 up to 13 on the S. F. A. website (Kaninikula Corpus). 
in the Children corpus. This could be due to the high level of dexterity required for implementing certain of these technical gestures.

I also noticed that some string figures made by children nowadays are no longer known by adults (who claim that they have forgotten them), even among the most expert: Morubikina, Bosioula and Bowelogusa, for instance, have forgotten how to make the kaninikula called dauta (name of a white bird) which is well known by almost every children I have met [Video 2 - S.F.A.]. This suggests that some procedures would be learnt in childhood, with the aim of training to be able to learn more complicated ones thereafter.

Another interesting example seems to indicate a progressive learning of string figure-making: the string figure kuluwawaya is the longest of the Oluvilei corpus. It allows to display a series of nine intermediate figures. I noted that some children know how to make the first figure of the series - a figure which has no name in Kilivila [29 - S.F.A.] - without being able to perform the complete procedure that would probably be learnt in a second stage.

\section{Conclusion}

My intention, in this paper, was to present some ethnographical data that offer leads for future research on the social roles and the cognitive aspects of string figure-making in the Trobriander society. Long-term fieldwork and a good knowledge of the language of the Trobriand Islanders (Kilivila) will be necessary to carry out this anthropological research. A thorough ethnolinguistic analysis of the technical terms used by the practitioners, while transmitting string figures, should help us to better understand how these actors perceive the cognitive acts that underlie the string figure procedures. Ethnolinguistic methods should also be applied to the study of the «oral texts» (vinavina) that sometimes accompany the making of string figures, as a way to further analyze the relationship between string figure-making and various forms of (ritual, cosmological, or mythological) knowledge in this society. When the practitioners recite the vinavina while making a series of string figures - as in the above examples of kuluwawaya, Tokwelasi, and dakuna - a parallel could be made with the pictographic sequences analyzed in the field of the anthropology of memory (Severi 2007, 2009). These examples allow us to hypothesize further that the making of such series of figures could be regarded as a genuine memory support, related to an "art of memory». In that perspective, it will be necessary to clarify the relationship(s) between oral text and image processing. In parallel, there is another promising direction of research: as mentioned in this article, the Trobriand Islands are divided into districts corresponding to different cultural areas characterized by linguistic variations (Senft, 1986). In each of these districts, I have recorded string figures which suggest that these procedures have circulated from one social group to another while being slightly transformed. Concerning (for instance) the four variants of the procedures kuluwawaya that I have collected in 2007 (Vandendriessche, 2010), it is noticeable that transformations have been implemented both at the level of the operations within the string figure procedures, and on the oral texts accompanying them. Such a double process of transformation might have been widespread as I collected other string figures that show similar changes through(out) the different districts. It remains to be better understood how these changes can be correlated with local cultural features. The processes of transmitting string figures deserves to be more generally investigated throughout the Trobriand Islands.

\section{Acknowledgements}

I am extremely grateful to Céline Petit, Gunter Senft and Pierre Lemonnier for their invaluable advice. This research would not have been possible without the financial support of the French Ministry of Research (Anthropology of mathematics project 2005-2009, Aide Concertée Incitative program), and the City of Paris (String figure-making: cognitive and cultural aspects of a mathematical practice project 2011-2015, Emergence(s) program 2011). I would also like to thank Philippe Mortimer for his careful polishing of this article. I completed the last version of this paper thanks to the generous hospitality of Prof. Dagmar Schäfer and the Max Planck Institut fuer Wissenschaftsgeschichte in Berlin (Sept-Dec 2014).

\section{Bibliography}

Ascher Marcia, 2002. Mathematics Elsewhere: An exploration of ideas across cultures, Princeton and Oxford, Princeton University Press.

Austen Leo, 1939. The Seasonal Gardening Calendar of Kiriwina, Trobriands Islands, Oceania 9, pp. 237-253.

BALl Walter William R., 1920. Mathematical Recreations and Essays (ninth edition), London, Macmillan and Co. 
Boas Franz, 1888. The Game of Cat's Cradle, Internationale Archiv für Ethnographie, Vol. I., pp. 229-230.

Claassen Stephan, Joseph D’Antoni and Gunter Senft, 2010. Some Trobriand Islands String Figures, Bulletin of the International String Figure Association 17, pp. 72-128.

Cunnington William A., 1906. String Figures and Tricks from Central Africa, Journal of the Royal Anthropological Institute of Great Britain and Ireland 36, pp. 121-131.

Damon Frederick H., 1990. From Muyuw to the Trobriands. Transformation Along the Northern Side of the Kula Ring, Tucson, The University of Arizona Press.

Fathauer George H., 1974. 'Trobriand'=, in D.M. Schneider and K. Gough, Matrilineal Kinship, Berkeley and Los Angeles, University of California Press, Chap. 4, pp. 234-269.

Gray John, 1903. Some Scottish String Figures, Man 3, pp. 117-118.

Haddon Alfred C., 1890. The Ethnography of the Western Tribe of Torres Straits, The Journal of the Anthropological Institute of Great Britain and Ireland 19, pp. 297-440.

-, 1912. Reports Of the Cambridge Anthropological Expedition to the Torres Straits, London, Cambridge University Press.

Haddon Kathleen, 1911. Cat's Cradles From Many Lands, Watchung (New Jersey), Albert Saifer Publications.

Hornell James, 1927. String figures from Fiji and Western Polynesia, Germantown, New York, Periodicals Service Co ed. Vol. 39, Bishop Museum (Reprint edition 1971).

JaYne Caroline F., 1962. String figures and How to Make Them: A Study of Cat's Cradle in Many Lands, New York, Dover Edition. (Reprint of the 1906 edition entitled String Figures, published by Charles Scribner's Sons, New York.)

Jenness Diamond, 1920. Papuan Cat's Cradles, Journal of the Royal Anthropological Institute 50, pp. 299-326.

-, 1924. Eskimo String figures. Report of the Canadian Arctic Expedition 1913-1918, F.A. Acland, Vol. XIII, Part B.

LandtMan Gunnar, 1914. Cat's Cradle of the Kiwaï Papuans, British New Guinea, Anthropos 9, pp. 221-232.

Malinowski Bronislaw, 1916. Baloma. The Spirits of the Dead in the Trobriand Islands, The Journal of the Royal Anthropological Insti- tute of Great Britain and Ireland 46, pp. 353430.

—, 1918. Fishing in the Trobriand Islands, Man 18, pp. 87-92.

-, 1920. Kula: The Circulating Exchange of Valuables in the Archipelagoes of Eastern New Guinea, Man 20, pp. 97-105.

-, 1922. Argonauts of the Western Pacific: An Account of Native Enterprise and Adventure in the Archipelagoes of Melanesian New Guinea, London, G. Routledge and Sons, Ltd; New York, E.P. Dutton and Co.

-, 1929. The Sexual Life of Savages in Northwestern Melanesia: An Ethnographic Account of Courtship, Marriage and Family Life among the Natives of the Trobriand Islands British New Guinea, London, G. Routledge and sons.

-, 1935a. Coral Gardens and their Magic, Vol 1. The Description of Gardening, London, George Allen and Unwine.

-, 1935b. Coral Gardens and their Magic; Vol 2. The Language of Magic and Gardening. London: George Allen and Unwine.

Maude Honor, 1978. Solomon Island String Figures, Canberra, Homa Press.

Noble Philip. D., 1979. String Figures of Papua New Guinea, Boroko, Institute of Papua New Guinea Studies.

PARKInson John, 1906. Yoruba String Figures, The Journal of the Anthropological Institute of Great Britain and Ireland 36, pp. 132-141.

Paterson Thomas. T., 1949. Eskimo String Figures and their Origin, Acta arctica 3, 98 p.

Persson Johnny, 1999. Sagali and the Kula. A regional system analysis of the Massim, Lund Monographs in Social Anthropology, 7.

Rivers William H. and Alfred C. Haddon, 1902. A Method of Recording String Figures and Tricks, Man 2, pp. 146-149.

Scaglion Richard, 1999. Yam cycles and Timeless Time in Melanesia, Ethnology 38, 3, pp. 211-225.

Senft Gunter, 1986. The language of the Trobriand Islanders, Berlin/New York, Mouton de Gruyter.

—, 1987. Rituelle Kommunikation auf den Trobriand Inselin, Zeitschrift fur Literaturwissenschaftund Linguistik 65, pp. 105-130. 
—, 1996. Past is present - Present is past: Time and the harvest rituals on the Trobriand Islands, Anthropos 91, pp. 381-389.

—, 1997. Magical Conversation on the Trobriand Islands, Anthropos 92, pp. 369-391.

-, 2011. The Tuma Underworld of Love: Erot$i c$ and other narrative songs of the Trobriand Islanders and their spirits of the dead, Amsterdam, John Benjamins.

Senft Barbara and Gunter Senft, 1986. Ninikula Fadenspiele auf den Trobriand inseln Papua NewGuinea, Baessler-Archiv 34, 1, pp. 93-235.

Severi Carlo, 2007. Le principe de la chimère: une anthropologie de la mémoire, Paris, Editions Rue d'Ulm/Presses de l'École normale supérieure.

—, 2009. L'univers des arts de la mémoire: anthropologie d'un artefact mental, Annales. Histoire, Sciences s ociales 64, 2, pp. 463-497.
Smith Harlan I., 1900. The Thompson Indians of British Colombia: Publications of the Jesup Pacific Expedition, by James Teit. Memoirs of the American Museum of Natural History, Vol.2; "Anthropology", Vol I, p. 281, Fig 270.

VAndendriessche Éric, 2007. Les jeux de ficelle: une activité mathématiques dans certaines sociétés "traditionnelles", Revue d'Histoire des Mathématiques 13, pp. 7-84.

-, 2010. String Figures as mathematics?, doctorat in Epistemology and history of sciences, Paris Diderot University, 587 p.

-, 2012. Kaninikula, Mathématiques aux îles Trobriand, Scientific Documentary, 26 MIN, to be diffused by CNRS Images (http://videotheque.cnrs.fr/index.php?urlaction=doc\&id_doc=4149\&rang=1).

WEINER Annett B., 1988. The Trobrianders of Papua New Guinea, New York, Holt, Rinehart and Winston. 